\title{
From empowering the shameful to shaming the empowered: Shifting depictions of the poor in 'reality TV'
}

\author{
Alana Barton \\ Edge Hill University, UK \\ Howard Davis \\ Edge Hill University, UK
}

\begin{abstract}
Poor-blaming and poor-shaming have become intrinsic parts of the neoliberal order. For neoliberal discourse to enter and to dominate wider public 'common sense', vehicles of 'populist language' are required and the mass media has taken a central place in propagandising neoliberalism through their narration of poverty. This article focuses on so-called 'reality TV' and its neoliberal framing of the poor, particularly since 2007 and specifically in its generation of support for, and acquiescence in, 'austerity'. We argue that what these programmes provide is a representation of poverty which is politically expedient but socially divisive. As criminologists, we suggest that this representation symbolises the intensification of what Cohen (2002: xxi) noted as the prominence of "'welfare cheats", "social security frauds" and "dole scroungers" as fairly traditional folk devils. Further, we argue that an intensification in the denigration of the poor and the marginal in these programmes can be traced across three phases, from 2009 onwards, defined by their key features. Whilst not neatly discrete, these phases mirror the neoliberal political shift from welfare to punishment. They manufacture 'epidemic problems' that are seen to require urgent remediation. Yet the status and nature of these problems are defined through deception and the forms of intervention required are determined through individualised and moralised neoliberal prescription.
\end{abstract}

\section{Keywords}

Austerity, benefits, neoliberal, poverty, reality TV

\section{Corresponding author:}

Alana Barton, Department of Law and Criminology, Edge Hill University, Ormskirk, Lancashire, L39 4QP, UK. Email: bartona@edgehill.ac.uk 


\section{Introduction}

For CW Mills (2000 [1959]), private troubles can only be understood in relation to public, structural issues. When one person is unemployed or in poverty or experiencing some other form of social exclusion or marginalisation, it is a private trouble but when millions experience such conditions it only makes sense as a structural, public issue. It cannot be explained as the product of individual deficits and misfortunes. In the absence of a Millsian sociological imagination, however, the opposite can become the case. In the post-financial crisis, its structural causes, and those of the economic, political and social crises that followed, have been almost magically erased. In their place an individualised, moralistic behavioural explanation has been distilled - that of 'broken Britain' (Slater, 2014).

Seeing poverty as a product of individual, familial and communal inadequacies is inherent to a neoliberal order that proclaims itself as meritocratic. Poor-blaming and poor-shaming have become intrinsic parts of that order. The mass media has taken a central place in propagandising neoliberalism through their narration of poverty. Over the last three decades, it has intensified a populist and increasingly authoritarian agenda that both derives and distracts from political disaffection and discontent. This article focuses on so-called 'reality TV' and its neoliberal framing of the poor, particularly since 2007, and, specifically, its generation of support for, and acquiescence in, 'austerity'. As we have argued elsewhere (Barton and Davis, 2013), the extent of the 'war', waged by political elites and bolstered by compliant media, against society's poorest is difficult to overstate and its subsequent social, psychological and economic harms demand urgent debate within criminology.

\section{Neoliberal ideology, poor-hate and 'reality TV'}

Antipathy towards the poor in the UK is rooted in long established political and economic processes and reproduced in populist ideologies. Since the 1980s, sustained and systematic reregulation in favour of 'free' markets has undermined social insurance and the collectivisation of risk. Workers' rights have been undermined and 'unstable' forms of employment have been expanded, whilst a 'business-friendly' state has 'reformed' welfare provisions. This has led to increasing dependency of workers on employers (Dardot and Laval, 2013), vulnerability to dangerous working practices (Tombs and Whyte, 2010), the deepening of social insecurities (Wacquant, 2009) and the creation of new 'precarious' groups (Standing, 2011). To self-manage 'market driven' insecurities (Bauman, 2011), neoliberal subjects are required to become ' ... entit[ies] in a competition, who must maximize [their] results by exposing [them]self to risks and taking full responsibility for possible failures' (Dardot and Laval, 2013: 261). Workers must respond to their insecurity by being 'enterprising', 'flexible' and 'competitive' (Giroux, 2014). In neoliberal rhetoric, work is constructed without irony as 'the privileged vehicle of self-realisation' (Dardot and Laval, 2013: 265) and workers themselves become beings 'all of whose subjectivity must be involved in the activity they are required to perform' (Dardot and Laval, 2013: 260). Employees are expected to work with dedication and enthusiasm, identifying with the 'missions' of their employers. They are expected to become, in Mills's terms, 'cheerful robots' (2000 [1959]) or, to use Bunting's (2004) description, 'willing slaves'. As the neoliberal crisis has bitten, however, the 'hardworking', 'taxpaying' 'cheerful robots' have become considerably less cheery. Previously contented groups have 
progressively come to experience precarity (Standing, 2011) and have become more open to messages of resentment.

Perversely, at the same time that ordinary individuals have become responsibilised for their failures in the market place, vast sums of public money have been used to 'bail out' the financial sector. With extraordinary audacity, measures targeting the unemployed, the disabled, the young and the working poor have been constructed as essential to pay for the aftermath of a crisis caused by financial and political elites - and even as protection for the next one (Osborne, cited in The Guardian, 2016). Despite the coalition government's claims that 'we are all in this together', the greatest costs of the crisis have been borne by those who did not contribute to it. Through the 'alchemy of austerity' (Jensen, 2014: para 2.1), the weakest social groups were targeted to pay for the massive market failures of casino capitalism. As a consequence, the poor, both employed and unemployed, have faced increasingly punitive conditions (Wacquant, 2009). Harsh, target driven approaches to benefit entitlements have shifted public focus downwards instead of upwards. Benefits were cut for those with a 'spare' bedroom. Draconian assessments for disabled people pronounced seriously ill claimants fit to work - sometimes with tragic consequences whilst at the same time inheritance tax and the top rate of income tax were reduced and the value of assets like bonds, shares and property was boosted through central bank quantitative easing. In 2014 Oxfam reported that when all austerity measures were taken into account, including cuts to public services and changes to welfare and taxes, between 2010 and 2014 the poorest tenth of the population experienced a $38 \%$ decrease in their net income. In contrast the richest tenth saw only a $5 \%$ fall in income. In the same years, the super-rich - the richest 1000 individuals held wealth of $£ 519 \mathrm{~b}$, a $55 \%$ increase in four years. Had this increase been distributed among all UK families, each would have been over $f 6000$ better off (Dorling et al., 2016). In the six years from 2009-2015, as austerity was imposed on the poor and the middling, the wealthiest 1000 doubled their wealth (Dorling et al., 2016).

This has been legitimised through the ideological denigration of the poor, dividing people of modest or low incomes against each other and reinforcing fear and mistrust of the economically 'marginal'. Politically generated and media disseminated ideological narratives, drawing on meritocratic myth, and blatantly misappropriating the concept of 'fairness', gained considerable public support. They have produced anxiety that some groups are getting 'special treatment' or other social privileges from the state (Valentine and Harris, 2014) - a 'something for nothing' myth that has reduced social relations to 'social combat' (Giroux, 2014). As Strong (2014: 117) states, insecurity is generated 'through the political-economic threat to the majority of having to support an undeserving population of "market failures"'. Alarmingly, there has been little evidence of any surge of empathy for those who have suffered most, or of solidarity between the insecure. Rather, the extreme challenges of 'surviving at the bottom of a savage neoliberal order' have helped distract attention from the structures that are really to blame (Giroux, 2014: 2). The notion of who 'we' are amidst the crisis has been transfigured: 'we' were the victims of elite greed and incompetence; now 'we' are righteous 'hardworking taxpayers'. 'We', in Nick Clegg's telling 2010 General Election soundbite, are 'alarm clock Britain', resentfully pulling back the bedclothes, whilst sleeping scroungers sponge 'on benefits'. As Hall et al. (1978: 156) noted nearly 40 years ago, political and media propaganda creates hegemonic 'common' sense attitudes which serve to disguise significant class differences, and at the same time 'establish[] a false coincidence of ideas between different classes. This coincidence then becomes the basis for the myth of a single, 
English kind of thought'. Through this 'single kind of thought', the poor have become 'national abjects' (Tyler, 2013: 47) and poor-hate has gained rapid political ascendancy.

Crucially, for neoliberal discourse to enter and dominate wider public 'common sense', vehicles of 'populist language' are required (Jensen, 2014). In this context, the genre of so-called 'reality TV' serves significant ideological functions. Reality television is not a new phenomenon. Arguably, as Friedman (2002) explains, the relationship between television and 'reality' can be dated back to the origins of television itself in that television represents the only medium that can broadcast visual images and sound as they occur in real time. The direct precedents of contemporary programmes can be traced to the 1940s and 1950s when new forms of live production created for the viewer a sense of 'real, as opposed to fabricated suspense' (Friedman, 2002: 4). Clissold (2004) gives the example of Candid Camera, first shown in the US in 1948, as the programme that foreshadowed many contemporary shows. It involved ordinary members of the public filmed via concealed cameras whilst being confronted with unusual (but deliberately setup) situations. Importantly, in addition to setting a blueprint for programmes using 'real' people as the source of entertainment, as Clissold (2004) argues, Candid Camera - created in the Cold War context of public and political paranoia and fear of surveillance - also represented how the genre could function as a conduit for broader social, political and/or ideological concerns.

By the late 20th century, reality TV began to reflect and reproduce neoliberal, rather than Cold War, concerns and anxieties. The genre became increasingly popular in the aftermath of the Writers' Guild of America strike in 1988 because, in terms of production, programmes did not rely on expensive scriptwriters or unionised professional actors (Grazian, 2010). Moreover, just as the production values of reality TV embody neoliberal economic principles, so 'narrative conventions reflect its morals [... and .... celebrate [its] radical right-wing values' (Grazian, 2010: 69). Specific behaviours, aspirations and routines are venerated or derided within ideological valorisation of individualisation, self-governance and 'free' consumerised choice (Ouellette and Hay, 2008). Neoliberalism's 'system of cruelty' is legitimised through the reiteration of ritualised performance across a range of programme types (Couldry, 2008). The premise of shows is frequently oppressive, exploitative and victimising. Contestants in Hell's Kitchen, for example, are required to live on the premises in which they 'work', are only allowed out with a chaperone and are subjected to haranguing and abuse. Those on Survivor live in shanty towns and 'literally starve while the world watches yet remain[s] on the couch' (Grazian, 2010: 69). The 'gamedoc' programme Big Brother enshrines the values and obligations of the neoliberal workplace: submission to constant surveillance and external authority; team conformity; individual responsibility; 'authentic' positivity and adherence to the goals of an organisation, institution or employer, become ritually performed (Couldry, 2008). These 'theatrical' representations transform the 'truths' of neoliberalism into acceptable norms. Ouellette (2004) argues that US show Judge Judy uses the trials of working class people to emphasise the values of the archetypal neoliberal citizen; self-enterprising, selfsufficient and able to function without state intervention. Further, as Kohm (2006) notes, Judge Judy is a stark example of the normalisation of neoliberal models of governance and, specifically, law and of the ways in which such models are directed towards particular vulnerable or marginalised groups.

Judge Sheindlin's insistence that any problem - no matter how systematic or rampant in society - is merely the fault of those who are caught up within it is a very powerful way of advancing 
a neoliberal agenda of cuts to social programs and the dismantling of the final vestiges of the welfare state. (Kohm, 2006: 716)

Neoliberal discourse has of course also underpinned other TV forms over recent years. 'Tabloid' talk shows of the 1990s (such as the US Oprah Winfrey Show or the UK's Trisha) which, through a focus on 'self-empowerment' (usually through personal confession), served to individualise a range of social problems. ${ }^{1}$ Programmes like Dragon's Den and The Apprentice have venerated the values of neoliberal entrepreneurship, endorsing the ruthlessness of 'business' and 'the market', applauding self-interest and, at the same time, ensuring that nearly every player will lose (Kelly and Boyle, 2012). 'Audiences', as Grazian (2010: 70) notes, 'expect layoffs at the conclusion of every episode'.

In the aftermath of the financial crisis of 2008 , reality TV in the UK took a new (although predictable) turn. As the material existence of marginal groups came under fierce political attack, a new set of 'reality' programmes began an unprecedented cultural assault on their behaviours, morals and lifestyles. Sometimes referred to as 'poverty porn' (Jensen, 2013) and forming part of what Giroux (2008) has called the neoliberal 'theatre of cruelty', these programmes, through the 'naturaliz[ation] [of] the ideology of broken Britain' became a central part of the narration of the socialisation of what had originally been a financial crisis (Tyler, 2014).

Neoliberalism, indeed, requires 'outsiders' or to use Tyler's (2013) term, 'national abjects'. Scapegoating and 'othering' justify the reproduction of its inequalities and injustices. In the reality TV programmes considered here, the weakest individuals and groups are reconstructed as economic and social threats. Refugees are transformed into 'benefit seekers', the unemployed into work-shy scroungers and the disabled into malingerers. In all, they are pitilessly constructed as feckless, immoral and parasitic. Rather than applauding neoliberalism's 'successes', as, say Big Brother or The Apprentice do, these programmes focus on the castigation of its losers. They individualise social problems, dislocate private troubles from public issues and 'seek biographical solutions to systemic contradictions' (Beck and Beck-Germshein, 2001: xxii). What is provided is a representation of 'poverty' which is politically expedient but socially divisive. We suggest that an intensification in the denigration of the poor and the marginal in these programmes can be traced across three overlapping phases, from 2009 onwards, defined by their key features:

- Neo-philanthropic 'empowerment' of the ('deserving') poor

- Neoliberal shaming of the unrespectable (but potentially redeemable) poor

- Derision of the unrespectable, unredeemable and shameless poor

These phases are not neatly discrete but they mirror the neoliberal political shift from welfare to punishment. They epitomise a 'theatre of cruelty' that is getting crueller. To be clear, we are not giving a systematic analysis of every programme. Rather, we offer some broad thematic reflections on the shifting nature of this form of reality TV. In particular, we highlight the contribution of such programmes to the production of ignorance about complex social processes in general and the generation of inequality in particular.

Agnotology, McGoey suggests (2012: 3), should address 'the political and social practices embedded in the effort to suppress or to kindle endless new forms of ambiguity and ignorance'. The ignorance and doubt generated - 'agnosis' - contribute towards a manufactured consent 
towards political and cultural hegemonies (in this case neoliberalism), acquiescence in their harmful consequences and the diminution or shifting of responsibility for those consequences. Some accounts of agnosis emphasise the creation of doubt towards scientific evidence in the interests of corporations: waters have been deliberately muddied, for example, around evidence of climate change and the dangers of asbestos and tobacco. A range of effective public relations strategies have been created in defence of profitable interests in such cases. However, ignorance can be contrived through a variety of means, not only the creation of doubt. The production of ignorance may include: direct censorship and suppression, misleading 'information management' - both formal and informal - the dissemination of false 'knowledge' and flawed systems of analysis and understanding. Whatever the specific intentional strategies and tactics or unintended structural/cultural/psychological forces that may be in play, the common element is the promotion of false understanding. Ignorance, read in this broad way, flourishes within and contributes to the reproduction of social and political cultures of indifference, coldness (Adorno, 1967) and intellectual and empathic 'de-imagination' (Barton and Davis, 2015; Giroux, 2014). Within such cultures, harmful untruths find ready acceptance, facilitated by public senses of political impotence, passivity and apathy (Barton and Davis, 2015). In this specific context, the willful and deliberate production of ignorance around poverty and welfare is propagated by politicians, 'pundits' and right-wing think-tanks (Slater, 2014). Reality TV programmes that scrutinise, 'expose' and moralise the lives of the poor are also deeply engaged in the process. They create the 'spectacle' of poverty. They manufacture 'epidemic problems' that seem to require urgent remediation. Yet the status and nature of these problems are defined through deception and the forms of intervention required are determined through individualised and moralised neoliberal prescription.

\section{Methods}

It was not the purpose of this research to conduct a scientific, quantitative sampling of all 'reality' television programmes that fell into the genres we outline above. Rather, our intention was to undertake a rigorous qualitative analysis of a range of programmes with the aim of drawing out discursive themes.

A total of 17 different programmes, consisting of 34 individual episodes, were viewed. Eleven of these programmes form the foundation of the analysis, ${ }^{2}$ whilst the remaining six ${ }^{3}$ were watched and analysed for the purposes of informing broader context. It was not possible to get access to every programme that fell into the genre and so programmes for analysis were selected primarily on the basis of their availability via personal recordings, Box of Broadcasts (an on-demand television for education service), YouTube and other internet sites.

Taking a qualitative approach, our primary aim was not to achieve broad representativeness in terms of the programmes selected, however it is notable that the programmes analysed were not unrepresentative or exceptional. The programmes were examined with regard to their representations of poverty and marginalisation, with particular focus on notions of 'causation' and blameworthiness. Specifically, employing inductive thematic analysis, the aim was to a) explore the portrayal of poverty and marginalisation, b) identify implicit and explicit ideas and meanings related to poverty and marginalisation and c) uncover themes of continuity and discontinuity across the range of programmes over the specified period of time. 


\section{Neo-philanthropic 'empowerment' of the ('deserving') poor: The largesse of the rich and famous in 'breadline Britain'}

Audiences are well used to celebrities attempting to 'make a difference', raising public awareness of (often global) problems. However, 2009 saw the development of this trope in the UK with programmes deploying celebrities to not only highlight, but to directly intervene in, problems such as unemployment, poverty and crime. Part celebrity vehicle and (allegedly) part social documentary, they accompanied rich and famous people providing 'deserving' (contrite) poor people with advice (e.g. ITV's 7 Days on the Breadline, Duchess on the Estate and Home Is Where the Heart Is) and/or skills (e.g. Gordon Behind Bars (Channel 4) and Football Behind Bars (Sky 1)) $)^{4}$.

The use of specific 'types' of celebrities in these programmes - those perceived as 'ordinary' despite their success and/or celebrities who have themselves experienced hardship or struggle simultaneously synthesised viewer interest and enhanced the dramatic appeal of the shows. For example, in the opening scenes of Football Behind Bars (Sky One, 2009) the narrator explained:

Ian Wright is a man on a mission. He passionately believes that football has the power to transform lives: like it did for him. [Cut to scenes of lan Wright scoring goals]. Now he's testing his faith in football inside the UK's prison system. [Cut to scenes of prison officers urgently running upstairs as if to an emergency, and prisoners talking of killings in prison]. He wants to turn 22 young criminals into footballers and change their lives forever so after they leave prison they will never come back.

Having served 14 days in prison as a younger man, Wright argued that if he was able to turn his life around through football others could do likewise. He stated that 'the sound of the prison doors closing and the nutters [sic] inside taught me I can't live my life like this' (Wright, 2007). ITV's 7 Days on the Breadline (2009) featured four celebrities (former Spice Girl Melanie Brown, makeover 'guru' Trinny Woodall, former rugby player Austin Healey and actor Keith Allen) ostensibly drawing upon personal experiences to provide 'expert' advice during one week with 'low income families' in Leeds (Guardian, 2009). 'Society girl' Trinny Woodall, for example, compared her own drug addiction with the slot-machine habit of pensioner, Christine.

Despite the premise of 'benevolence', and the no-doubt genuine concern of the celebrities, their intervention clearly emanated from the obsessive neoliberal illusion of personal responsibility. They were poverty tourists and the poor person was the spectacle: a juxtaposition of the wealthy luminary and the deprivation into which they were parachuted. As Tanya Gold (2014) noted, reviewing these programmes, they represented an 'AK-47 of fleeting and synthetic empathy [where t] he lesson is simply the familiar narcissism of the ruling class: the most interesting thing about poverty is what a blow it is to those who don't have to live in it'. The show's producer David Flynn remarked: 'Our celebrities are going to step into the shoes of people on the estate and it will be compelling to see how they cope and if they can make a difference' (Endemol UK, 2010, emphasis added). Celebrity participant Keith Allen, commented:

I'm expecting hardship. But I'm also in a way kind of looking forward to trying to get under the skin of the people and finding out how they cope with hardship and if they perceive it as 
hardship. I think foremost I'd like to get the message across 'don't let the bastards grind you down'. (TV Throng, 2009)

Similarly, Melanie Brown enthused that 'anything that takes you out of your comfort zone and gives you a chance to challenge yourself is always rewarding' (Brown, 2009).

In Duchess on the Estate (ITV, 2009), Duchess of York Sarah Ferguson made several visits to the Northern Moor council estate in Wythenshawe, Manchester. She was inspired to extend her previous work against obesity to the plight of the 'underclass'. She explained her experience of the problem: 'Young people go out with their mobile telephones and their knives now. I've noticed a lot more violence, I've noticed bad language. Literally, you can't get some young people to do joined up writing, let alone joined up sentences' (Express, 2009). Putting to one side the question of how, precisely, the Duchess had come to 'notice' these things, her dysphoric vision of the nation (casually collapsing issues without any discernible evidence of a social science education) was contrasted with deeply nostalgic historical references to a past golden age of solid respectable families and 'tight-knit' communities. Accordingly, the Duchess looked beyond everyday problems. She wanted to instill good old fashioned 'community values'. Her plan was in equal measures simple, self-regarding and facile:

I inspire people to get on and do things by rallying the troops. I'm an enabler. What saved people after the blitz was a cup of tea and a biscuit ... I mean, going back to the Queen Mother, you know it was after World War II that Britain was so famous for 'a cup of tea and a biscuit' ... We listened and we talked to each other so much more ... (ITV, 2009)5

In another interview with GMTV (14 August 2009), the Duchess of York again talked about this 'community spirit':

I've always wanted to bring community spirit back to Britain ... I think it's time for more of talking to each other and listening to each other and the mothers and the women and the people of Northern Moor ... they wanted to get some pride back in their area. So I went up there, spent some time up there, talking to them ... and say 'ok, what do you want to do' and they said 'we want to, you know, put flower pots back, we want to get everybody talking ... so there is hope...

Her solution for the estate, beset she claimed by unemployment, crime and drugs, was for the

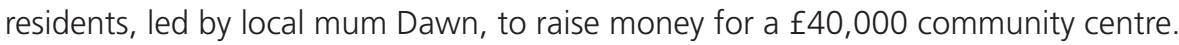

Celebrities in these programmes often represented the viewer. And whilst they communicated sympathetically with real people suffering real problems, it is the people, not the problems that were subjected to questioning. The subject was presented both as a unique individual (with whom the celebrity could establish an inter-personal relationship) and as a generalised subject (representing a broader body of people that the viewer could enjoy not relating to). Narratives reconfigured personal accounts within popularist expectations, norms and agendas. They assuredly:

... d[id] not enable the individual to transcend the narrow milieux in which [they lived], or truly connect them with the larger realities of what [wa]s happening in the world. On the contrary 
they obscured these connections by distracting [their] attention and fastening it upon artificial frenzies that [we]re resolved within the programme framework. (Mills, 2008: 114)6

Such 'frenzies' are achieved through a form of 'neo-philanthropism' (Villadsen, 2008). There was a clear missionary purpose in these shows. Wedded to self-help, personal responsibility and the individualisation of social problems, they rested upon the motivation, 'empowerment' and thus rehabilitation of those outside neoliberal ideals. Structural realities disappeared (Vander Schee and Kline, 2013) and the responsibilised poor became dependent on the charitable expertise of their selfless celebrity advisors. Difficulties were reconstructed as moral failures. The aim in such neoliberalised strategies of 'empowerment' is to revitalise the 'positive core' of the recipient (Villadsen, 2008). Subjects must recognise and take control of their problems. Self-esteem and self-development become the magic keys to overcoming the myriad interrelated and structurally produced challenges of poverty. Thus, the 'good' neoliberal citizen - one who is self-governing and self-reliant even in the most adverse circumstances - is constructed (Ouellette and Hay, 2008). The glaring contradictions inherent, for example, in 'empowering' men behind bars or people living below the breadline are ignored. 'Empowerment' becomes a simulated concept and nothing like meaningful liberation or emancipation. What we see instead is 'performed empowerment'. Viewer comments that followed these programmes praised those participants who demonstrated their acquiescence towards 'expert' prescription. Those by contrast who openly resented the intrusion of celebrities and camera crews into their lives, such as the teenager who told Mel B to 'fuck off', became the objects of cyber-opprobrium.

In sum, this first raft of programmes offered 'neoliberalised' understandings of social welfare. Celebrity endorsement of 'self-help' supplanted any genuine understanding of the structural generation of poverty and the necessity of public welfare (Vander Schee and Kline, 2013). At a time when political elites were noisily signalling increasingly restricted conceptions of their responsibilities for social security, this form of reality TV offered 'informal' guidelines for living, endorsing neoliberal notions of governing from a distance (Kelly and Boyle, 2012; Ouelette and Hay, 2008). Whilst the poor were not viewed inhumanely, failure to properly perform endeavour or gratitude indicated recalcitrance - grounds for moral censure both in programme narration and internet commentary.

\section{Neoliberal shaming of the unrespectable (but redeemable) poor: 'Bilking and milking the system'}

Around 2009-2010, reflecting the intensification of the political 'war on public services' (BBC, 2010), reality TV programmes turned from celebrity facilitated 'empowerment' of the marginalised towards 'exposure' and shaming of their 'dysfunctional' lifestyles. This second 'phase' of programmes includes those that are often referred to as 'poverty porn'. ${ }^{7}$ This term does not refer to the offensiveness or 'obscenity' of poverty but rather, as Jensen (2013) explains, to the exploitative motives and practices of programme makers, who set out to produce superficial representations of the poor that require 'no interpretative work from the viewer' but which incite in the audience a powerful, judgemental and usually condemnatory response. 
The most obvious distinction between these programmes and those above is the absence of the celebrity 'mediator' between viewer and subjects. ${ }^{8}$ A voiceover narrator and interviewer are present although the latter is not always seen or heard. Generally, subjects appear to speak directly to the audience, with their 'voices' unmediated. However, they are clearly edited and viewers are given strong narrative and visual steers as to how they should frame what they are witnessing. The 'spectacle' in these programmes is the poor themselves and the role they play in their own failures, and subsequently, stigmatisation.

Take Channel 4's Benefits Street, for example. ${ }^{9}$ Although the first episode is relatively sympathetic to its subjects, sections of the programme are clearly designed to provoke the ire of viewers. 'Career criminal' Danny, demonstrating his shoplifting skills and candidly stating that he doesn't want to work because he is a 'lazy dickhead', is one example. Young couple Mark and Becky, clearly struggling with two young children on $\mathrm{f30}$ per week reduced benefits, admit to having previously brought in around $\mathrm{f} 1500$ per week through fraudulent claims. Although the stories presented in these programmes are exceptional, they are presented as, and thus can be readily mistaken for, the norm. But perhaps even more aggravating to a 'time poor' precariat audience (Standing, 2011), James Turner Street residents sometimes enjoy their 'time rich' lives - drinking, smoking and congregating on doorsteps or on settees in the street. Patently incongruous with the neoliberal model of the (self-) disciplined worker, 'worklessness' becomes reconstructed as a decadent indulgence rather than structural privation.

Worklessness as a personal and cultural choice is a key feature of the agnosis around 'broken Britain'. Government strategy to manage the aftermath of the financial crisis has been to construct a perception of a society with large numbers of people unnecessarily dependent on welfare benefits (Hancock et al., 2012). For example, in 2006 the so-called Centre for Social Justice identified five 'pathways to poverty'. These were: family breakdown; educational failure; addiction; serious personal debt; and economic dependency and worklessness (typically conceived as due to individual inadequacies and a counter-productive welfare system).

Despite weak and/or manipulated evidence for these claims (MacDonald et al., 2014; Standing, 2011) the 'problem' of worklessness in particular developed political and social currency and numerous 'workfare' arrangements were introduced. ${ }^{10}$ A combined 'incentives and consequences' approach (DWP, 2012) included: the introduction of a benefit cap (to ensure 'everyone had the same incentive to work' (DWP, 2012: 39, emphasis added)); the creation of The Work Programme (a welfare-to-work pay-by-results strategy introduced in 2011 and outsourced to a range of (often private sector) organisations); the Work Choice scheme ('helping' unemployed disabled people to adapt to the demands of the workplace); and increased sanctions for claimants who did not 'fulfil their responsibilities' (DWP, 2012: 39, emphasis added). Corroboration for the worklessness myth from self-perpetuating political and media rhetoric has propagated new forms of 'commonsense' about poverty, disability and unemployment (Jensen, 2014).

The BBC's Trouble on the Estate, for example, filmed on the Shadsworth Estate in Blackburn, aimed to uncover what it was like to grow up and live on 'one of the most deprived [areas] of the country' (BBC, 2012a), highlighting the problems of '[d]rugs, anti-social behaviour, family breakups and joblessness ...' on an estate which 'on average, per person, had one of the highest welfare bills in the country' (BBC, 2012b). Linking explicitly with government discourse, the programme presented 'a picture of "Broken Britain" - a place at the edge of where the state can make a difference' (BBC, 2012a). 
Benefit Busters (2009) on Channel 4 further naturalised workless, 'broken Britain'. The programme featured Hayley, a trainer for A4E (Action for Employment, a private company paid by the government to find work for the long term unemployed) delivering a 'positive thinking' session to a group of lone parents wanting to get back into work. She asked them: 'Why aren't you all queueing up outside MacDonald's, Burger King and KFC then? ... Why aren't you all queuing up outside their door if you all want a job so badly?' The unseen narrator confirmed the need for 'reform':

The bill for social security benefits keeps on rising. It's now more than all the income tax paid by British taxpayers put together... A fair system that is tough on the work-shy and supportive to those who are desperate to work has eluded all political parties ... This government's radical idea is to award large contracts to private sector companies and charities and reward them for getting claimants back to work ... Paying by results has given rise to a new breed of benefit buster. (Emphasis added)

Hayley told her jobless lone parents '[t]here is not one of you in this room who cannot go out and get a job tomorrow and that is a fact' (Studio Lambert, 2015). The message was that social security was unaffordable and benefits regimes were insufficiently tough on the 'work-shy'. However, the biggest proportion of national 'benefits' spending was, and still is, on state pensions - approximately $47 \%$. At no point did this programme - or any other programme in the genre target pensioners. In 2014, from a bill of $£ 150$ billion, less than $0.6 \%$ was spent on Job Seekers' Allowance, far less than was spent topping up the incomes of those in low paid jobs. In these programmes the familiar myths were peddled that not working is a matter of choice and that 'joblessness' is the result of a lack of will. At the end of the course, A4E managed to find four trainees two-week, unpaid placements in Poundland. They were informed that paid employment might follow if they proved 'good enough'. With exquisite irony, A4E (which became People Plus in 2015) was itself dogged by financial scandal, falsifying the number of its claimed 'successes' and defrauding the DWP on this basis. The investigations resulted in prison sentences for a number of employees (Guardian, 2015).

On this note, in addition to the myth of 'worklessness', numerous programmes embellished their accounts of poverty with the supposed 'epidemic' of benefit fraud. This was crucial: to justify cutting benefits claimants needed to be constructed as undeserving. One way to do this was to present them as 'cheats', people too lazy to work when they could 'fiddle the system' instead. In 2013, the BBC programme Britain on the Fiddle claimed to explore the 'runaway problem of benefit fraud' (emphasis added), whilst the series Saints and Scroungers (launched in 2009 and now in its seventh series) 'follow[ed] fraud officers as they bust[ed] the benefit thieves stealing millions of pounds every year'.11 As official figures show, however, money defrauded from welfare expenditure is only a fraction of that lost through tax avoidance and evasion. Figures from the Department of Works and Pensions, the Insurance Fraud Bureau and HMRC indicate that the cost of benefit fraud amounts to around $\mathrm{f} 1.1$ billion (Guardian, 2014). Yet $\mathrm{f2.1}$ billion in benefits remain unpaid due to error. Meanwhile, the estimated difference between the tax that should be collected if the system operated effectively and the amount actually collected has been estimated at $\mathrm{f35}$ billion by HMRC itself (Guardian, 2013). Tax Research UK estimate the figure to be $£ 119$ 
billion. Either way, the problem of benefit fraud pales into insignificance alongside money 'lost' to tax avoiders and evaders. ${ }^{12}$

Putting financial agnosis to one side, perhaps the most pernicious aspect of these programmes has been the demarcation they have established between the 'respectable' poor and the 'unrespectable' poor. They have consolidated 'shared norms' around the powerful binary of 'skiver' and 'striver', or 'worker' and 'shirker', which 'conceives of ... citizens as one or the other, occupying different spaces, orientated by different morals, aspirations and values' (Jensen, 2014: para 2.5). BBC1's Saints and Scroungers explicitly bolstered two myths - that benefit claimants could be categorised one-dimensionally as 'good' or 'bad', and that for every genuine claimant there was a sponger fleecing the system. BBC1's Nick and Margaret: We All Pay Your Benefits also epitomised this ideological division. ${ }^{13}$ The programme brought four benefit claimants and four 'taxpayers' (notwithstanding that benefits recipients pay tax themselves) 'face-to-face to explore each other's lives ... and speak their minds' (BBC, 2013). Needless to say, the claimants were not chosen because they claimed child benefit or the state pension. 'Workers' and 'shirkers' were undisputed categories and presented as if belonging to either group were a matter of choice. For presenters Nick and Margaret unemployment was alien. Margaret stated 'the benefits world is not something I know anything about' (emphasis added) whilst Nick replied 'me neither ... we're the explorers' (emphasis added). The 'taxpayers' made disapproving judgements about the lifestyles of the claimants: that they visited a betting shop, owned pets, had tattoos, owned an iPhone and even, quite astonishingly in the case of one mother, bought a chicken to provide a hot meal for her children when they did not need a hot evening meal as they had eaten a school lunch. The ideological message of 'less eligibility' could hardly be clearer. Self and social worth are equated solely with paid employment. For example, in keeping with government reforms that force single parents to actively seek employment or lose their benefits once their child reaches the age of five (to be reduced to the age of three in 2017), childrearing is presented as an excuse to not work. As working mother Cheryl commented, after meeting unemployed father of four Luther in We All Pay Your Benefits, 'I don't think that wanting to stay at home [to look after children] is a good enough reason to not work'. The 'casualties' of neoliberalism deserve no sympathy. They deserve punishment.

Although the distinction between 'them' and 'us' in these programmes was not explicitly racially constructed, they were not without sharp racialised and xenophobic components. Refugees, whilst a 'hyper-precarious' group experiencing serious physical, material and psychological hurt (Waite et al., 2014), were constructed as threats, physically, economically, psychologically and spatially. As Dorling notes (2014: 144), more broadly 'migrants' have been deliberately labelled as '... the source of the problem in housing, employment ... education [and] health in countries where the rich increasingly monopolise living space, salaries, schools and health spending'. In 2014, in a follow up to We All Pay Your Benefits, BBC1 aired Nick and Margaret: Too Many Immigrants? The programme required a group of 'British-born' anti-immigration participants to spend time with (legal, we are specifically informed) immigrants working in the UK. At the end of the show the 'British-borns' decide if immigration is, in the words of presenter Nick Hewer 'a gain on the country, or simply a drain'. Despite claims that it attempted to challenge those with anti-immigration views, like its many predecessors the show served to reduce an extremely complex subject to the most simplistic dichotomy. 


\section{Derision of the unrespectable, unredeemable and shameless poor: From voyeuristic altruism to voyeuristic hate}

Confirming that the televisual spectacle of poverty was far from exhausted, in 2013 a new rhetorical device was exercised by Channel 5 with its ... and Proud series of programmes. Beginning with On Benefits and Proud, the ideological message was that claiming benefits was something of which one should be ashamed (as the claimant) or suspicious (as the 'hardworking taxpayer') something more akin to theft than an entitlement. This was especially evident when the programme was seen in the context of the other episodes in the series which featured a range of criminal and anti-social activity (Shoplifters and Proud (2013), Pickpockets and Proud (2013), Football Hooligans and Proud (2014), Dangerous Dog Owners and Proud (2014) and ASBO and Proud (2014)). The use of shame and humiliation for entertainment is well established within various television genres. As Presdee (2000) demonstrates, from talk shows to game shows, the ritualised shaming of (often vulnerable) people has been a well-used programme trope for several decades. In terms of the more recent 'poverty shaming' genre, the greatest vitriol has been saved for those who, regardless of their privations, remained unembarrassed, unapologetic or seemingly content with their lot. This rage against the defiance of the 'shameless' was nothing new. To quote Adorno:

[a] pattern that has been confirmed throughout the entire history of persecutions is that the fury against the weak chooses as its target especially those who are perceived as societally weak and at the same time - either rightly or wrongly - as happy. (1967: 2)

Being shameful has increasingly become a condition for (public and political) empathy and support. Shame acknowledges the poor person's failings and lays open their inadequacies. It may not quite involve begging but it is about asking for help humbly and being suitably grateful. The poor are not to claim welfare in a spirit of citizenship and entitlement but, rather, as supplicants. For Jo (2013), shame may decrease the empathy gap between shamed and shamer. Whilst this relationship between shame and poverty is clearly disempowering for the shamed, Jo argues that it can allow the non-poor to develop an understanding around some of the complex difficulties the poor face, so reducing negative judgement. However, programmes like those in the ... and Proud series represent a vicious manipulation of this relationship. Relying on the converse implication - that where poverty is represented as shameless, or even as defiant or proud, empathy will be diminished - these programmes provide selected (unrepresentative) poor people platforms through which they (are prompted to) condemn themselves through their psychosocial shamelessness. Whether they are simply resistant to being shamed, or 'empowering' themselves by claiming entitlements without guilt, they are, it is contended, proud.

On Benefits and Proud introduced unemployed mother Heather Frost. The focus was the number of children she had (11) and the amount of public money spent on keeping them accommodated. The constant reminders that Heather had 11 children carried a clear message - that this was something of which the audience would disapprove and something of which Heather should be ashamed. Yet careful editing ensured that Heather appeared, not ashamed, but 'proud' (or at least, unashamed). Clips of Heather shrugging or looking dismissive were coupled with a voiceover 
informing the audience she was unconcerned about the public money spent on combining two council houses in order to accommodate her family. After the show was aired, Heather was subjected to a barrage of abuse and threats from members of the public. Despite Heather looking after 11 children, and another of the show's participants Julie having six children, the narrator trilled 'their only graft is working the system', cueing shots of Julie and partner Vinny watching their satellite TV packages, clearly with the aim of causing public resentment that 'people on benefits in this country [we]re not in fact entertaining themselves with shadow puppets' (New Statesman, 2013). Later, when they received their benefit payment, the narrator informed us that 'with unexpected money in the bank, it [was] time to spend'. What we actually observed however was Julie and Vinny at the local shop paying for electricity, gas and one can of beer.

Gypsies on Benefits and Proud (2014) escalated the hatred stakes by playing on the (by now familiar) resentments towards immigrant groups. In one episode, we met 25 year old Viorel Dinu, a Romanian immigrant who had lost both legs in a rail accident when he was a child and now moved around on a skateboard. The narrator informed the audience that ' $[$ b] lack home Viorel had to beg to get by so life here is a relative luxury thanks to 750 quid a month in job seekers and disability living allowances, ten times what he would get in Romania'. One week after the show aired Viorel was attacked by a former soldier, angry at his appearance on the show. The attacker's defence lawyer stated in court that his client 'was annoyed that this man was claiming benefits when he should not have been' (Northern Echo, 2014). The Echo recounted 'A legless Gypsy busker who bragged on National TV about "milking the benefits system" had to face the music when confronted by an irate viewer' (emphasis added). Meanwhile the Daily Mail (2014) reported 'Ex-soldier attacked amputee gypsy [sic] busker who bragged on TV about milking Britain's benefit system after he recognised him in the street'. Yet at no point in the programme did Viorel 'brag' or say he was 'milking the system'. On the contrary his attitude was one of gratitude and he (and other Gypsies featured) talked about how grateful they were for their opportunities in the UK. That Viorel 'faced the music' - itself a telling euphemism for straightforward assault - is implicitly condoned by straightforward media lies.

\section{Conclusion}

At this juncture it is appropriate to return to the question of why these programmes should be of concern to criminologists. There currently exists a small, but important, body of criminological literature, from the UK and abroad, concerned with the interplay between reality TV, crime, law, criminal justice and neoliberal models of governance, control and punishment. For example, in his analysis of Border Security: Australia's Front Line, Walsh (2015: 202) argues that by exploiting 'neoliberal globalization's dislocating features and their attendant consequences' the programme serves to align public anxieties with notions of 'security risks' and 'external threats' (emphasis added). Through the association of particular groups, such as illegal immigrants, with risk and danger, and the representation of state agents as 'heroic' protectors, state agendas are effectively legitimised. For Kohm (2009), reality TV can constitute part of broader social control and criminal justice apparatus at a real as well as an ideological level. Using the example of NBC's Dateline: To Catch A Predator (a programme in which journalists, local police and an internet watchdog group use hidden cameras to lure, trap, confront and in many cases arrest suspected paedophiles), he 
contends that the message is two-fold: first, that 'communities are under attack and the only way to fight back is to be perpetually on the lookout for crime' and second, that the mass media can be seen as a 'private sector solution to the "law and order" crisis' (Kohm, 2009: 194). ${ }^{14}$

But, as critical criminologists our concerns must stretch beyond legal definitions of 'crime', the remit of criminal justice and concepts of official 'law and order'. As we have demonstrated in this article, there currently exists an extensive range of programmes that demonise not just serious criminal offenders but those who are poor and, consequently, vulnerable. Presented as social pariahs who threaten social values, if not safety, these are the people that perhaps would once have been considered 'at risk' rather than 'risky'. Importantly, these objectified representations of the poor, the unemployed, immigrants and other marginalised groups found in this genre of 'reality TV' have real, serious and harmful consequences. Despite the unqualified and unsubstantiated claims made in many of the programmes, they have been seized upon by politicians as evidence, and thus as a means of bolstering the rhetoric of 'broken Britain'. The (heavily mediated) depictions of a small number of individuals and communities became the means for politicians to connect with the electorate by plugging into a (misdirected) sense of outrage in order to legitimise the implementation of harmful austerity policies.

In the House of Commons, Conservative backbencher Simon Hart bemoaned that there was a Benefits Street 'in every constituency in the land' (BBC, 2014), whilst for Conservative MP for Shipley Philip Davies the programmes clearly demonstrated that benefits were too generous (Telegraph and Argus, 2014). Davies argued that after watching On Benefits and Proud he was struck by 'the number of people ... who manage to combine complaining about welfare reform with being able to afford to buy copious amounts of cigarettes, have lots of tattoos, and watch Sky TV on the obligatory widescreen TV'. His outrage was compounded because of the 'concerns and irritations of many people who go to work every day and pay their taxes but cannot afford those kinds of luxuries' (Telegraph and Argus, 2014). For Davies, one street resident in particular epitomised all that was wrong with 'benefits Britain'. Deidre Kelly (aka 'White Dee'), despite being assessed by the state as eligible for disability benefits and being credited by neighbours as a caring and community spirited woman, was described by Davies as 'bone idle' and someone who 'doesn't want to work another day in her life and has no intention of finding a job' (Daily Star, 2014).

Referring to Benefits Street and accepting without question the programme's depiction of welfare claimants, lain Duncan Smith joined in the fray, remarking that 'many people are shocked by what they see ... That is why the public back our welfare reform package, which will get more people back to work and end these abuses' (Daily Mirror, 2014, emphasis added). Benefits Street, according to Smith, revealed the existence of 'welfare ghettos', a 'twilight world' of entire communities happily reliant on welfare support (Dominiczac, 2014). Even the Prime Minister David Cameron stressed the importance of the 'Benefits Street message' which was 'to help people out of ... poverty and benefit dependency' (ITV, 2015, emphasis added).

The combination of these mediated representations and the powerful, yet largely unsubstantiated, political rhetoric around welfare dependency and welfare abuse ensured that complex, but hardly incomprehensible, issues became reduced to simplistic, individualised and ireful discourses in which the real problem of poverty was explained as the burden it placed on the better off. ${ }^{15}$ This was not redressed by the subsequent Big Benefits Row and Benefits Britain: The Live Debate programmes (aired in 2014 by Channel 5 and Channel 4 respectively and later followed by The Big Can't Pay Debate, The Big Fat Row Debate and The Big British Immigration Row, all 
on Channel 5). ${ }^{16,17}$ The Big Benefits Row was, according to Channel 5, to be led by a panel of 'experts'; yet, like the other similar 'debate' programmes, this consisted of politicians, journalists and a host of 'TV personalities' or 'celebrities'. There were no 'expert' economists or social scientists. Instead, 'debate' was replaced by 'journalistic commentary and opinion polls - whose primary function [was] to comment on representations as if they were real' (Jensen, 2014). Owen Jones (2014) has referred to this format as the 'Hopkinisation' of political discourse, whereby 'the mantra of mainstream politicians and journalists about people at the bottom of society [is repeated] but with even fewer facts and more venom' ${ }^{18}$

In a context where anti-intellectualism in both popular culture and politics is extoled, where 'common sense' is fetishised and informed debate is replaced by facile entertainment and spectacle, ignorance prevails. For Giroux (2014: 47), this means the 'rendering of all social problems as biographical in nature' creating a 'reactionary public pedagogy' and the worst kind of 'public' politics. Ignorance is created - but it is an ignorance which leaves the public feeling as if they are informed. As Chomsky et al. (1998: 43) put it: 'The smart way to keep people passive and obedient is to strictly limit the spectrum of acceptable opinion, but allow very lively debate within that spectrum ...'.

Not surprisingly, public attitudes are hardening. Research carried out by NatCen examined changing public attitudes to poverty and welfare. They found that the relationship between economic circumstances and attitudes to welfare had shifted over the last three decades, with the public increasingly more likely to blame individual characteristics rather than societal issues as the cause of poverty (Rae, 2013).

Of course this shift cannot be solely blamed on reality TV depictions. Nor can it be claimed that there is complete public acceptance of and support for the ideologies they espouse. Indeed, as Tyler (2014) notes, Benefits Street 'emerged as the site of dense and fractious struggle, amongst the residents of James Tuner Street, television producers, television viewers, politicians, newspaper journalists, television pundits, anti-poverty groups, policy-makers and sociologists' (see also Jensen, 2013; Skeggs and Wood, 2012; Tyler, 2013). But when coupled with a strident anti-poor political discourse (from across the political parties), disseminated through misleading tabloid reportage, it is not difficult to see how such ideas, or rather ignorance, gains currency. Coldness and indifference proliferate whilst empathy diminishes, especially with those most socially marginalised and excluded. As Giroux (2014: 9) has noted, what we are witnessing is '... a near sociopathic lack of interest in - or compassion and responsibility for - others'. The poor and weak are openly ridiculed and derided in the name of entertainment, blamed for mass economic harms that were not of their making and directly harmed by public and political responses. Therein lies the crucial matter at stake for criminologists.

\section{Funding}

This research received no specific grant from any funding agency in the public, commercial, or not-for-profit sectors.

\section{Notes}

1. See Peck (2010) for a discussion of Oprah Winfrey in relation to the neoliberal political-economic project.

2. These consist of the following, with the individual number of episodes in brackets: 7 Days on the Bread- 
line (3); Duchess on the Estate (2); Gordon Behind Bars (4); Football Behind Bars (6); Nick and Margaret: We All Pay Your Benefits (1); Nick and Margaret: Too Many Immigrants? (1); Benefits Street Series 1 (5); Trouble on the Estate (1); Benefit Busters (3); On Benefits and Proud (1); Gypsies on Benefits and Proud (1).

3. These consist of: Jamie Oliver's Food Revolution; Home Is Where the Heart Is; The Alan Titchmarsh Show; GMTV; Saints and Scroungers; Britain on the Fiddle.

4. Viewing figures are not routinely available without a significant subscription to the Broadcast Audience Research Board and thus cannot be provided for every programme referred to in this article. However, other sources can give an indication of audience numbers and these are provided where possible. 7 Days on the Breadline achieved viewing figures of 3.7 million (Guardian, 2009) and Gordon Behind Bars reached 3 million (Radio Times, 2012), thus indicating the popularity of these shows.

5. There is little if any historical research into the significance of British tea and biscuits in the failure of German aerial bombing during the Second World War. Nor is there research into whether German shortages of tea and biscuits contributed to the 'success' of Allied mass bombing of civilians in the latter part of the war.

6. Note that in this quote Mills was referring to the operation of the mass media in general but we feel his comments are particularly pertinent to the reality TV genre. Further, his use of the term 'frenzies' more aptly describes a sense of excitement or agitation created by these early programmes, as opposed to wider fears (as connoted by the concept of moral panic) which were perhaps more readily exploited by later shows.

7. This phase includes: Saints and Scroungers (BBC, 2009); Benefit Busters (Channel 4, 2009); The Scheme (BBC Scotland, 2010); Trouble on the Estate (BBC, 2012); Benefits Britain 1949 (Channel 4, 2013); Nick and Margaret: We All Pay Your Benefits (BBC, 2013); People Like Us (BBC, 2013); Skint (Channel 4, 2014); Benefits Street (Channel 4, 2014); Benefits Britain: Life on the Dole (Channel 5, 2015); Benefits and Bypasses (Channel 5, 2015).

8. The exceptions here are the BBC show Saints and Scroungers (2009 onwards, which features wellknown presenters Dominic Littlewood and, later, Matthew Allwright) and the BBC programmes featuring Nick Hewer and Margaret Mountford (e.g. Nick and Margaret: We All Pay Your Benefits and Nick and Margaret: Too Many Immigrants?).

9. According to The Guardian (2014), Benefits Street attracted 4.3 million viewers, the highest ratings for any Channel 4 programme in 2013 (representing a $17.2 \%$ audience share).

10. The myth of intergenerational worklessness has been exposed by Shildrick et al. (2012) who state that the proportion of workless households with two generations who have never worked constitutes only $0.5 \%$ of all workless households. They found no evidence of three generations of worklessness.

11. In 2010 Saints and Scroungers pulled in 4.3 million viewers, representing the highest ratings (22.6\% audience share) for its pre-primetime slot of 7.30pm to 8pm (Mediatel, 2010).

12. Nonetheless, the problem has clearly roused public concern. The benefits fraud hotline (emotively titled 'Targeting Benefit Thieves') receives on average 600 calls per day (Guardian, 2014). The tax fraud hotline (which has the more sober title of 'Report Tax Evasion') is also actively used by the public, although not to the same degree, receiving around 300 calls per day mostly to report tradespeople taking cash in hand payments for small jobs, and has not led to any real increase in tax revenues (Telegraph, 2013).

13. In this programme (which was termed 'an ambitious experiment' by the BBC), TV celebrities Nick Hewer and Margaret Mountford aim 'to discover how much benefit is enough to live on and if work is worth it' because 'the country is more divided than ever about how much of our taxes should be spent on benefits for the unemployed' (BBC, 2013). This programme scored the highest ratings, outside of serial dramas (soaps) on 11 July 2013, with 4.55 million viewers or a 22.9\% audience share (Digital Spy, 2013).

14. Kohm also refers to programmes such as America's Most Wanted and Crimewatch UK as similar examples within this genre.

15. Through this discourse those in poverty are reconstructed as the blameworthy group, indeed the cause of their own, and others', privations. This is at a time when the government's own statistics have indicated that 2380 people died between December 2011 and February 2014 after being declared 'fit for work' and thus having their sickness and disability benefit claims rejected (Ryan, 2015). It is not known 
how all of these people died but it is interesting that the DWP issued written guidance on suicide and self-harm threats from clients for those staff tasked with informing people their claims had been rejected (Domokos, 2011).

16. In The Big Can't Pay Debate, the extent of household debt in Britain was to be discussed in order to determine if this was the fault of banks and financial institutions or the individuals that 'get themselves into debt'.

17. The use of the term 'row' rather than 'debate' clearly indicates the type and level of discussion intended. This programme netted 2.13 million viewers (Televisual, 2014)

18. By 'Hopkinisation', Jones is referring to right wing TV personality and newspaper columnist Katie Hopkins. Hopkins was condemned by many in 2015 when she referred to migrants as 'cockroaches' in her Sun newspaper column.

\section{References}

Adorno T (1967) Education after Auschwitz. Available at: http://ada.evergreen.edu/ arunc/texts/frankfurt/ auschwitz/AdornoEducation.pdf (accessed 21 June 2016).

Barton A and Davis H (2013) The politics of crime and the crimes of politics: Where does criminology stand in the 'war on the poor'? European Group for the Study of Deviance and Social Control: Autumn Newsletter. Available at: http://www.europeangroup.org/?q=node/56.

Barton A and Davis H (2015) Neoliberalism, higher education and anti-politics: The assault on the criminological imagination. In: Frauley J (ed) C. Wright Mills and the Criminological Imagination: Prospects for Creative Inquiry. Farnham: Ashgate, pp. 201-218.

Bauman Z (2011) Collateral Damage: Social Insecurities in a Global Age. Cambridge: Polity Press.

BBC (2010) Budget: Government 'declaring war' on public sector. 22 June. Available at: http://www.bbc. co.uk/news/10379329 (accessed 21 June 2016)

BBC (2012a) Panorama: Trouble on the Estate. 11 September. Available at: http://www.bbc.co.uk/mediacentre/proginfo/2012/37/trouble-on-the-estate.html (accessed 21 June 2016).

BBC (2012b) Growing up on Blackburn's troubled Shadsworth estate. 11 September. Available at: http:// www.bbc.co.uk/news/uk-19547168 (accessed 21 June 2016).

BBC (2013) Nick and Margaret: We All Pay Your Benefits. Available at: http://www.bbc.co.uk/programmes/ b036yrm8 (accessed 21 June 2016).

BBC (2014) PMQs: Benefit Street 'in every constituency' says MP. 15 January. Available at: http://www.bbc. co.uk/news/uk-politics-25746824 (accessed 21 June 2016).

Beck U and Beck-Gernsheim E (2001) Individualization: Institutionalized Individualism and Its Social and Politi$\mathrm{cal}$ Consequences. London: Sage.

Brown M (2009) My week in Apathy City: Living with a family on benefits. Daily Mail, 27 October. Available at: http://www.dailymail.co.uk/tvshowbiz/article-1222661/MEL-B-My-week-Apathy-City-living-familybenefits.html (accessed 21 June 2016).

Bunting M (2004) Willing Slaves: How the Overwork Culture is Ruining our Lives. London: Harper Collins.

Chomsky N, Barsamian D and Naiman A (1998) The Common Good. Monroe, ME: Odonian Press.

Clissold BD (2004) Candid Camera and the origins of reality TV: Contextualising a historical precedent. In: Holmes S and Jermyn D (eds) Understanding Reality Television. London: Routledge, pp. 33-53.

Cohen S (2002) Folk-Devils and Moral Panics: The Creation of the Mods and Rockers. Abingdon: Routledge.

Couldry N (2008) Reality TV, or the secret theatre of neoliberalism. Review of Education, Pedagogy, and Cultural Studies 30(3): 3-13.

Daily Mail (2014) Ex-soldier attacked amputee gipsy busker who bragged on TV about milking Britain's benefit system. 5 September. Available at: http://www. dailymail.co.uk/news/article-2745218/AmputeeGipsy-busker-no-legs-bragged-Channel-5-TV-programme-milking-Britain-s-benefits-attacked-street-exsoldier.html (accessed 21 June 2016).

Daily Mirror (2014) Iain Duncan Smith suggests hit show Benefits Street justifies savage welfare cuts. 13 January. Available at: http://www.mirror.co.uk/news/uk-news/benefits-street-iain-duncan-smith-3019449 (accessed 21 June 2016). 
Daily Star (2014) Tory MP blasts Benefits Street star White Dee over booming TV career. 20 February. Available at: http://www.dailystar.co.uk/news/latest-news/366310/Tory-MP-blasts-Benefits-Street-star-WhiteDee-over-booming-TV-career (accessed 21 June 2016).

Dardot P and Laval C (2013) The New Way of the World: On Neoliberal Society. London: Verso.

Department for Work and Pensions (DWP) (2012) Social Justice: Transforming Lives. March. HMSO, Cm8314. Available at: https://www.gov.uk/government/uploads/system/uploads/attachment_data/file/49515/ social-justice-transforming-lives.pdf (accessed 21 June 2016).

Digital Spy (2013) Nick and Margaret's 'We All Pay Your Benefits' interests 4.5 million. 12 July. Available at: http://www.digitalspy.com/tv/ratings/news/a497879/nick-and-margarets-we-all-pay-your-benefitsinterests-45-million/ (accessed 15 September 2016).

Dominiczac P (2014) lain Duncan Smith: I'll stop Benefits Street Britain. The Telegraph, 22 January. Available at: http://www.telegraph.co.uk/news/politics/conservative/10590933/lain-Duncan-Smith-III-stop-Benefits-Street-Britain.html (accessed 21 June 2016).

Domokos J (2011) Jobcentre staff sent guidelines on how to deal with claimants' suicide threats. The Guardian, 8 May. Available at: https://www.theguardian.com/society/2011/may/08/jobcentre-staff-guidelinessuicide-threats (accessed 21 June 2016).

Dorling D (2014) Inequality and the 1\%. London: Verso

Dorling D, Rinvolucri B and Green L (2016) Is inequality an unavoidable fact of life? Available at: http://www. dannydorling.org/?page_id=2921 (accessed 21 June 2016).

Endemol UK (2010) 7 Days on the Breadline. 1 June. Available at: www.endemoluk.com/news/article/7-dayson-the-breadline (accessed 21 June 2016).

Express (2009) Hoodies to Fergie: "You toffee nosed git". 11 August. Available at: http://www.express.co.uk/ news/uk/119790/Hoodies-to-Fergie-You-toffee-nosed-git (accessed 21 June 2016).

Friedman J (2002) Introduction. In: Friedman J (ed) Reality Squared: Televisual Discourse on the Real. London: Rutgers University Press.

Giroux H (2008) Slouching towards Bethlehem: The new gilded age and neoliberalism's theatre of cruelty. Dissident Voice, March 11. Available at: http://dissidentvoice.org/2008/03/slouching-towards-bethlehem/ (accessed 21 June 2016).

Giroux H (2014) Neo-liberalism's War on Higher Education. Chicago, IL: Haymarket Books.

Gold T (2014) After Benefits Street, it's another round of poverty porn - with added celebrity. The Guardian, 5 March. Available at: https://www.theguardian.com/commentisfree/2014/mar/05/benefits-streetpoverty-porn-celebrity-bbc (accessed 21 June 2016).

Grazian D (2010) Neoliberalism and the realities of reality television. Contexts 9(2): 68-71.

Guardian (2009) Seven Days on the Breadline lures 3.7 million. 21 October. Available at: http://www.theguardian.com/media/2009/oct/21/tv-ratings-seven-days-on-the-breadline (accessed 21 June 2016).

Guardian (2013) UK's tax gap rises by $f 1$ bn to $f 35 b n$. 11 October. Available at: http://www.theguardian. com/politics/2013/oct/11/uk-tax-gap-rises-hmrc-avoidance-nonpayment (accessed 21 June 2016).

Guardian (2014) Channel 4's Benefits Street claims 4.3 million viewers. 7 January. Available at: https://www. theguardian.com/media/2014/jan/07/tvratings-channel4 (accessed 15 September 2016).

Guardian (2015) Welfare-to-work company employees to be sentenced for fraudulent claims. 30 March. Available at: http://www.theguardian.com/uk-news/2015/mar/30/a4e-welfare-work-company-workerssentenced-fraud (accessed 21 June 2016).

Guardian (2016) George Osborne warns of further cuts as storm clouds gather. 26 February. Available at: http://www.theguardian.com/politics/2016/feb/26/george-osborne-further-cuts-storm-clouds-economicbudget (accessed 21 June 2016).

Hall S, Critcher C, Jefferson T et al. (1978) Policing the Crisis: Mugging, the State and Law and Order. London: Macmillan.

Hancock L, Mooney G and Neal S (2012) Crisis social policy and the resilience of the concept of community. Critical Social Policy 32(3): 343-364.

ITV (2009) Alan Titchmarsh Show. 9 March.

ITV (2015) ITV News. 12 May. Available at: http://www.itv.com/news/tyne-tees/2015-05-12/david-cameronweighs-in-to-benefits-street-row/ (accessed 21 June 2016). 
Jensen T (2013) A summer of television poverty porn. The Sociological Imagination. Available at: http://sociologicalimagination.org/archives/14013 (accessed 21 June 2016).

Jensen T (2014) Welfare commonsense, poverty porn and doxosophy, Sociological Research Online 19(3). Available at: http://www.socresonline.org.uk/19/3/3.html (accessed 21 June 2016).

Jo YN (2013) Psycho-social dimensions of poverty: When poverty becomes shameful. Critical Social Policy 33(3): 514-531.

Jones O (2014) Owen Jones on The Big Benefits Row: The Hopkinsisation of political discourse. The Independent, 4 February. Available at: http://www.independent.co.uk/voices/comment/owen-jones-on-thebig-benefits-row-the-hopkinsisation-of-political-discourse-9106227.html (accessed 28 September 2016).

Kelly LW and Boyle R (2012) The Television Entrepreneurs: Social Change and Public Understanding of Business. Farnham: Ashgate.

Kohm SA (2006) The People's Law versus Judge Judy: Two models of law in American reality-based courtroom TV. Law and Society Review 40(3): 693-728.

Kohm SA (2009) Naming, shaming and criminal justice: Mass mediated humiliation as entertainment and punishment. Crime, Media, Culture 5(2): 188-205.

MacDonald R, Shildrick T and Furlong A (2014) 'Benefits Street' and the myth of workless communities. Sociological Research Online 19(3). Available at: http://www.socresonline.org.uk/19/3/1.html (accessed 21 June 2016).

McGoey L (2012) Strategic unknowns: Towards a sociology of ignorance. Economy \& Society 41(1): 1-16.

Mediatel (2010) Newsline. 2 September. Available at: http://mediatel.co.uk/newsline/2010/09/02/tv-overnightscrimewatch-solved-wins-the-peak-hour-with-over-4-million-viewers/ (accessed 15 September 2016).

Mills CW (2000 [1959]) The Sociological Imagination. New York: Oxford University Press.

Mills CW (2008) Mass society and liberal education. In: Summers H (ed) The Politics of Truth: Selected Writings of CW Mills. Oxford: Oxford University Press, pp. 107-124.

New Statesman (2013) On Benefits and Proud: The show where 'deserving taxpayers' stalk 'proud benefit claimants'. 15 October. Available at: http://www.newstatesman.com/culture/2013/10/benefits-andproud-show-where-deserving-taxpayers-stalk-proud-benefit-claimants (accessed 21 June 2016).

Northern Echo (2014) Ex-soldier convicted after racially threatening legless Romanian Gypsy over 'scrounger' comments. 5 September. Available at: http://www.thenorthernecho.co.uk/news/11456462.Ex_soldier_convicted_ after_racially_threatening_legless_Romanian_Gypsy_over_scrounger_comments/(accessed 21 June 2016).

Ouellette L (2004) Take responsibility for yourself: Judge Judy and the neoliberal citizen. in: Murray $S$ and Ouellette L (eds) Reality TV: Remaking Television Culture. New York: New York University Press, pp. 223-342.

Ouellette L and Hay J (2008) Better Living Through Reality TV: Television and Post-Welfare Citizenship. Malden, MA: Blackwell.

Oxfam (2014) The True Cost of Austerity and Inequality: UK Case Study. Oxford: Oxfam. Available at: https:// www.oxfam.org/sites/www.oxfam.org/files/cs-true-cost-austerity-inequality-uk-120913-en.pdf (accessed 21 June 2016).

Peck J (2010) The secret of her success: Oprah Winfrey and the seductions of self-transformation. Journal of Communication Inquiry 3(1): 7-14.

Presdee M (2000) Cultural Criminology and the Carnival of Crime. London: Routledge

Radio Times (2012) Gordon Behind Bars detains 3m viewers on Channel 4. 27 June. Available at: http://www. radiotimes.com/news/2012-06-27/gordon-behind-bars-detains-3m-viewers-on-channel-4 (accessed 15 September 2016)

Rae G (2013) Tough on people in poverty - new report shows public's hardening attitudes to welfare. Joseph Rowntree Foundation. Available at: https://www.jrf.org.uk/press/tough-people-poverty-\%E2\%80\%93new-report-shows-public\%E2\%80\%99s-hardening-attitudes-welfare (accessed 21 June 2016).

Ryan F (2015) Death has become a part of Britain's benefits system. The Guardian, 27 August. Available at: https://www.theguardian.com/commentisfree/2015/aug/27/death-britains-benefits-system-fit-for-worksafety-net (accessed 21 June 2016).

Shildrick T, MacDonald R, Furlong A et al. (2012) Are 'cultures of worklessness' passed down the generations? Joseph Rowntree Foundation, December. Available at: http://wbg.org.uk/pdfs/worklessness-families-employment-full.pdf (accessed 21 June 2016). 
Skeggs D and Wood H (2012) Reacting to Reality Television: Performance, Audience and Value. Abingdon: Routledge.

Slater T (2014) The myth of "Broken Britain": Welfare reform and the production of ignorance. Antipode 46(4): 948-969.

Standing G (2011) The Precariat: The New Dangerous Class. London: Bloomsbury Academic.

Strong S (2014) Underclass ontologies. Political Geography 42: 117-120.

Studio Lambert (2015) Benefit Busters. Available at: http://www.studiolambert.com/benefit-busters.html (accessed 21 June 2016).

Telegraph (2013) "Tax-dodgers" hotline receives 300 tip-offs per day. 17 June. Available at: http://www. telegraph.co.uk/finance/personalfinance/tax/10124794/Tax-dodgers-hotline-receives-300-tip-offs-a-day. html (accessed 21 June 2016).

Telegraph and Argus (2014) Tory hits out after documentary shows claimants spending cash on cigarettes, new tattoos and Sky TV. 15 January. Available at: http://www.thetelegraphandargus.co.uk/news/10936454. Shipley_MP_Philip_Davies_says_benefits_ttoo_generous__after_watching_Channel_4_s_Benefits_ Street/?ref=twtrec (accessed 21 June 2016).

Televisual (2014) Channel 5 gets $2 \mathrm{~m}$ viewers for live benefits debate show. 4 February. Available at: http:// www.televisual.com/news-detail/Channel-5-gets-2m-viewers-for-live-benefits-debate-show_nid-3858. html (accessed 15 September 2016).

Tombs S and Whyte D (2010) A deadly consensus. British Journal of Criminology 50(1): 46-65.

TV Throng (2009) 7 Days on the Breadline. 21 October. Available at: http://www.tvthrong.co.uk/tag/7-dayson-the-breadline/ (accessed 21 June 2016).

Tyler I (2013) Revolting Subjects: Social Abjection and Resistance in Neoliberal Britain. London: Zed Books.

Tyler I (2014) Being poor is not entertainment: Class struggles against poverty porn. Social Action and Research Foundation. Available at: http://www.the-sarf.org.uk/being-poor-is-not-entertainment-classstruggles-against-poverty-porn-by-imogen-tyler/ (accessed 21 June 2016).

Valentine G and Harris C (2014) Strivers vs skivers: Class prejudice and the demonisation of dependency in everyday life. Geoforum 53: 84-92.

Vander Schee C and Kline K (2013) Neoliberal exploitation in reality television: Youth, health and the spectacle of celebrity concern. Journal of Youth Studies 16(5): 565-578.

Villadsen K (2008) Freedom as self-transgression: Transformations in the 'governmentality' of social work. European Journal of Social Work 11(2): 93-104.

Wacquant L (2009) Punishing the Poor: The Neoliberal Government of Social Insecurity. Durham, NC: Duke University Press.

Waite L, Valentine G and Lewis H (2014) Multiply vulnerable populations: Mobilising a politics of compassion from the 'capacity to hurt'. Social and Cultural Geography 15(3): 313-331.

Walsh J (2015) Border theatre and security spectacles: Surveillance, mobility and reality-based television. Crime, Media, Culture 11(2): 201-221.

Wright I (2007) This much I know. The Observer, 5 August. Available at: http://www.theguardian.com/theobserver/2007/aug/05/features.magazine57 (accessed 21 June 2016).

\section{Author biographies}

Alana Barton, PhD, is a Senior Lecturer in Criminology at Edge Hill University, UK. Her recent research and published work focuses on austerity and the 'war on the poor'; criminological epistemology and the neoliberal university; 'agnosis', ignorance and the criminological imagination; and 'dark tourism' and the prison.

Howard Davis, PhD, is a Senior Lecturer in Criminology at Edge Hill University, UK. He has a longstanding research interest in the origins of, impact of and responses to trauma and loss. Other recent research and publications are in the fields of disaster management and response; the criminological and political dimensions of 'austerity'; criminological epistemology; and state and corporate crime. 